\title{
Substantiation of a rational method of purification of sugar sorghum juice in the technology of food syrup production
}

\section{Nataliia Hryhorenko, Nataliia Husiatynska, Olha Kalenyk}

\author{
National University of Food Technologies, Kyiv, Ukraine
}

\section{Keywords:}

Sugar sorghum

Syrup

Flocculant

Zeolite

Ultrafiltration

Article history:

Received

28.07.2020

Received in revised

form 28.02.2021

Accepted

30.06.2021

Corresponding author:

Nataliia Hryhorenko

E-mail:

grygorenko.na@ gmail.com

DOI:

$10.24263 / 2304-$

974X-2021-10-2-5

\section{Abstract}

Introduction. The purpose of research is to establish patterns for removal of macromolecular and color compounds, using different methods of purification sugar sorghum juice to obtain food syrup.

Materials and methods. Sugar sorghum hybrid 'Mamont' was used as a feedstock for food syrup. Native sorghum juice was subjected to enzymatic treatment to hydrolyze starch. For extraction of sugar-soluble non-sugars from sorghum juice, including macromolecular substances (MMS) and dyes, the cationic flocculant polyhexamethylene guanidine hydrochloride (PGMG GC) and natural mineral sorbent zeolite were used. Membrane filtration methods and ion exchange purification were used to intensify the purification process.

Results and discussion. Due to the use of zeolite at an optimal cost of $0.8-1.0 \%$ by weight of the juice, the discoloration effect is achieved at the level of $41-46 \%$, and the effect of removal of the MMS by $20-22 \%$.

The use of zeolite for purification of sorghum juice in combination with membrane filtration methods, such as mechanical filtration and ultrafiltration leads to improved technological performance of sorghum juice. Under these purification conditions, sugar sorghum juice with a purity of $90.72 \%$ and a colour of 245.8 ICUMSA units was obtained, and the efficiency of purification, removal MMS and proteins substances was $46.1,82.3$ and $69.5 \%$, respectively.

Under the conditions of supplementing the above-method with ion exchange purification, we obtained an increase in the efficiency of purification, removal of the MMS and proteins in accordance with the values of 51.9, 98.5 and $89.2 \%$.

Proposed methods of purification of sugar sorghum juice are effective in removing MMS, proteins and colored compounds and provide food syrups in which the optimal ratio of carbohydrates sucrose and glucose and fructose $(65: 35) \%$ by weight of total sugar.

Conclusions. The best quality indicators were syrups obtained by purification methods, which included the use of adsorption purification with zeolite, membrane filtration and ion exchange purification. 


\section{Introduction}

The priority of sugar sorghum over other sugar-bearing crops is that the juice of sugar sorghum stalks contains from 14 to $20 \%$ of carbohydrates, with sucrose amounting to $60-80 \%$ and reducing compounds $20-40 \%$. In addition, the juice is a source of biologically active substances; it contains amino and organic acids, polyphenols, proteins, vitamins, and minerals (Eggleston G. et al., 2013; Umakanth A.V. et al., 2013). Most of the components present in the juice prevent the crystallisation of sucrose. Therefore, the juice is concentrated into a syrup that is transparent and has a mild taste, while the fructose present in it gives it a barely noticeable honey tone (Zhetkizgenkyzy G. et al., 2016). Basing on the analysis of the chemical composition of sugar sorghum syrup, that it can be compared (Willis O.O. et al., 2013) with sugar cane syrup; however, due to the high content of phenols and flavonoids, the syrup has excellent antioxidant properties, which allows its use in the food industry as a product with functional properties. Thus, obtaining food syrup from sugar sorghum is a good basis for the development and production of biologically valuable foods (Kovtunova N.A. et al., 2019; Karputina M. et al., 2014).

It was developed (Vukov K., 1987) a technology to a syrup, which included shredding stalks, juice settling, centrifugation, filtration and thickening into syrup. These studies are not technologically complete and require additional research to ensure that the syrup is of proper quality.

It is offered (Costa G. H. G. et al., 2015; Eggleston G. et al., 2016; Albuquerque F., 2011) to carry out clarification of sugar sorghum juices by application of various chemical reagents. Thus, it is suggested to clarifysugar sorghum juices using coagulants of calcium hydroxide and magnesium oxide (Costa G. H. G. et al., 2015) that are used for the removal of non-sugars from juice in the production of sugar from sugar cane (Albuquerque F., 2011). Therefore, using magnesium oxide coagulant by adding it to sorghum juice to $\mathrm{pH} 6.0$ and 7.0 reduced the amount of sludge, phenolic compounds, and ash in the clarified juice, as well as improved the dynamics of the decantation process and the quality of the juice. When using calcium hydroxide, the starch content in the juice decreased. At the same time, during the decantation of non-sugars with calcium hydroxide at $\mathrm{pH} 7.0$, the volume of the sludge increased.

For the production of an industrial batch of syrup, a technology was tested (Eggleston G. et al., 2016), which involved the decantation of deaerated juice in decantation tanks, hotpurification of juice at $80^{\circ} \mathrm{C}$, defecation to $\mathrm{pH} 6.5$ with lime milk at an application rate $360 \mathrm{~g} / \mathrm{l}$ and by adding $5 \mathrm{ppm}$ of polyanionic flocculant. In general, the proposed technology allowed to obtain an industrial batch of syrup of proper quality, as well as ensured uninterrupted supply of syrup to the consumer. At the same time, there is no information on the technological quality of the obtained product.

However, in the case of the use of chemical reagents in the technology of obtaining food syrup for further use as a ready food product, there is an urgent need for additional control of the source product for residual concentrations of chemical reagent in the end product.

It is proposed to use filtration and decantation of juice without the use of chemicals to obtain high-quality syrup (Nimbkar N. et al., 2006).

It is considered (Csefalvay E. et al., 2019) the possibility of using various existing technologies for the production of syrup based on the production of sugar from sugar beet and sugar cane. The efficiency of four-stage technology without using chemical reagents is shown, which provides centrifugal separation of insoluble starch from sorghum juice, application of ultrafiltration to remove proteins and microorganisms, nanofiltration to 
concentrate carbohydrates to a dry matter content of $25 \%$, and vacuum concentration to syrup. Under such conditions, it is almost possible to preserve the carbohydrate component, close to its initial ratio in the source juice. However, little information on indicators of technological quality of the product.

It was (Ospankulova G. et al., 2020) proposed a multi-stage scheme of juice clarification, which included mechanical filtration of juice, hydrolysis of starch by amylolytic enzymes, centrifugation, decolourisation of juice with active charcoal, chitosan treatment, sucrose inversion by enzyme invertase at a low-temperature evaporation mode $\left(+58{ }^{\circ} \mathrm{C}\right)$. Under such conditions, good quality syrup with a slight accumulation of 5hydroxymethylfurfural during storage and no reaction of crystallization of sucrose was obtained. The proposed technology is overloaded with technological processes, which is not always an economically sound solution.

Meanwhile, the effectiveness of natural sorbents, in particular zeolite, for clearing sugar sorghum juice, has not been studied. At the same time, the researchers (Husiatynska N. et al., 2018) proposed to use natural zeolite to improve the production quality of diffusion juice in the production of sugar from sugar beets.

Therefore, an important issue in the technology of obtaining a high-quality sugarcontaining product is the maximum preservation of the carbohydrate component and useful biologically active compounds of sorghum juice.

The aim of the research was to establish the regularities of removal of macromolecular and colouring compounds when using different methods of sugar sorghum juice purification to obtain food syrup. To achieve this goal, the following tasks were identified:

- To carry out comparative studies of different methods of sugar sorghum juice purification in order to choose the optimal conditions of the process without the involvement of chemical reagents;

- To establish the efficiency of sugar sorghum juice clarification with zeolite sorbent and to determine effective methods of zeolite application in combination with membrane and ion exchange filtration methods at the stage of juice purification in processing natural sorghum juice;

- To establish the optimal application rate of zeolite sorbent for the process of juicepurification in order to improve production quality of the juice;

- To investigate the degree of removal of macromolecular compounds, proteins and colouring compounds from sorghum juice.

\section{Materials and methods}

\section{Materials used in the experiment}

Natural zeolite with fractions $<0.3$ (powder), $0.2-0.5 \mathrm{~mm}$, and $1-3 \mathrm{~mm}$ (Transcarpathian Zeolite Plant, Sokyrnytsia, Khust district, Zakarpattia region, Ukraine.

Chemical reagent, cationic flocculant, is developed on the basis of polyhexamethylene guanidine hydrochloride (PHMG-HC) (20.0 $\pm 1.5 \%$ mass), which belongs to low-hazardous substances (hazard class 4) and has approval for drinking water purification and solutions (Gembickij P.A. et al., 1998).

Membrane purification methods (Membrany, 2005), which involved the use of mechanical filtration, on a polypropylene cartridge filter Ecosoft $2.5 \times 10$ " with a filtration degree of 5-10 $\mu \mathrm{m}$ and ultrafiltration on a membrane Aqua filter TLCHF-2T with a filtration degree of $0.02-0.1 \mu \mathrm{m}$. 
Ion exchange regenerating mixture of resins DOWEXMB-50 of mixed action in the ratio of cations in $\mathrm{H}^{-}$form and anions in $\mathrm{OH}^{-}$form of 1.2:1.0, with a granule size of $0.35-1.2$ $\mathrm{mm}$ and a total exchange capacity (g-equivalent/l) $1.8 \mathrm{H}^{+}$and $1.0 \mathrm{OH}^{-}$(Dow Chemical LLC).

Sorghum stalks of sugar hybrid 'Mamont' (the breeder: Odesa Breeding and Genetic Institute - National Centre of NAAS) were used as a feedstock. They were harvested in the stage of milky-wax ripeness in the experimental field of the Institute of Bioenergy Crops and Sugar Beet NAAS (Ksaverivka 2, Vasylkiv district, Kyiv region). Cell juice was obtained from stems, which were previously cleaned of leaves and squeezed on a roller press. The obtained sorghum juice was filtered. Its physicochemical characteristics were determined in the average juice sample (Table 1).

Technological indicators of sugar sorghum juice

Table 1

\begin{tabular}{|l|l|}
\hline Index & Average value \\
\hline $\mathrm{H}^{+}$activity & $5.0 \pm 0.22$ \\
\hline Dry matter (DM), \% & $15.8 \pm 0.26$ \\
\hline Macromolecular compounds (MMS), \% DM & $12.1 \pm 0.38$ \\
\hline Proteins, \% & $0.87 \pm 0.1$ \\
\hline Starch, \% & $3.1 \pm 0.3$ \\
\hline Total sugars, \% & $12.9 \pm 0.1$ \\
\hline Reducing sugars, \% & $4.5 \pm 0.05$ \\
\hline Sucrose, \% & $8.4 \pm 0.05$ \\
\hline
\end{tabular}

\section{Pre-clarification of sugar sorghum juice}

Extraction of sugars from sorghum stalks was performed by pressing (Grigorenko, N.O. et al., 2017). The resulting juice, due to the content of natural starch, was subjected to enzymatic treatment (Hryhorenko N. et al., 2007). Hydrolysis of starch reduces the viscosity of juices during purification and increases the sugar content in the juice. The natural sorghum juice was heated to a temperature of $95-100{ }^{\circ} \mathrm{C}$ and kept at this temperature for $8 \pm 3$ min for thermal coagulation of the MMS and proteins (Hryhorenko N. et al., 2007). Then the juice was cooled to the optimal for enzymes temperature and two-stage enzymatic hydrolysis of starch was carried out as follows: (1) dextrinization and simultaneous dilution of starch were performed with the addition of the enzyme product ( $\alpha$-amylase) in the amount of 2.5-3.0 units per $1 \mathrm{~g} \mathrm{DM}$ of starch for $30 \pm 10 \mathrm{~min}$; (2) saccharification of dextrins to glucose was performed with the addition of glucoamylase in the amount of 3.0-4.0 units per $1 \mathrm{~g}$ of DM starch for $30 \pm 10$ minutes. The resulting juice was used for research to purify and thicken to a syrup.

Technological characteristics of sorghum juice after enzymatic hydrolysis of starch are shown in Table 2.

\section{Sorghum juice purification}

Chemical reagents, natural adsorption mineral materials, membrane filtration methods, and ion exchange purification were used to cleansugar sorghum juice from macromolecular and colouring compounds. The proposed methods are shown in Table 3. 
Technological characteristics of sorghum juice after fermentation

Table 2

\begin{tabular}{|l|l|}
\hline Index & Value \\
\hline $\mathrm{H}^{+}$activity & 5.22 \\
\hline Dry matter (DM), \% & 16.3 \\
\hline Proteins, \% & 0.68 \\
\hline Macromolecular compounds (MMS), \% DM & 10.90 \\
\hline Total sugars, \% & 13.70 \\
\hline Reducing sugars, \% & 4.93 \\
\hline Sucrose, \% & 8.77 \\
\hline Purity, \% & 84.05 \\
\hline
\end{tabular}

Methods of sugar sorghum juice purification

Table 3

\begin{tabular}{|l|c|c|c|c|}
\hline \multicolumn{1}{|c|}{ Processes } & $\begin{array}{c}\text { Treatment1 } \\
\text { (control) }\end{array}$ & $\begin{array}{c}\text { Treatment } \\
\mathbf{2}\end{array}$ & $\begin{array}{c}\text { Treatment } \\
\mathbf{3}\end{array}$ & $\begin{array}{c}\text { Treatment } \\
\mathbf{4}\end{array}$ \\
\hline Pre-purification & + & + & + & + \\
\hline Chemical clarification & + & & & + \\
\hline Adsorption purification & & + & + & + \\
\hline Mechanical filtering & + & + & + & + \\
\hline Ultrafiltration & + & & + & + \\
\hline Ion exchange purification & & & & + \\
\hline Concentration & + & + & + & + \\
\hline
\end{tabular}

In order to effectively extract soluble non-sugars from sorghum juice, including MMS and colouring compounds, a chemical reagent, namelycationic flocculant polyhexamethylene guanidine hydrochloride (PHMG HC), and natural mineral sorbent, zeolite-clinoptilolite, were used in the research.

Treatment 1 - control. It is based on our previously developed technology (Hryhorenko N. et al., 2020), which provided removal of MMS and colouring substances after pre-purificationusing PHMG HC at an application rate of $0.004-0.005 \%$ a.i. and a temperature of $60{ }^{\circ} \mathrm{C}$ for 30 minutes, followed by separation of the coagulated sludge by filtration with a perlite filler on a vacuum filter and carrying out additional ultrafiltration of sorghum juice on a polyethylene terephthalate membrane with a pore diameter of $0.08-0.15$ $\mu \mathrm{m}$.

All purification methods stipulated concentration of purified juice to syrup with a dry matter content of $70-75 \%$. The concentration process was performed using a laboratory rotary vacuum evaporator at a temperature of $60-80{ }^{\circ} \mathrm{C}$.

Treatment 2. After pre-purification of the juice, to remove coagulated non-sugars and mechanical impurities, adsorption purification with sorbent zeolite-clinoptilolite in the amount of $1.0 \%$ masswas carried out at a temperature of $40{ }^{\circ} \mathrm{C}$ for $8-10$ min followed by membrane filtration, i.e. mechanical filtration on the polypropylene cartridge filter Ecosoft $2,5 \times 10$ "with a filtration degree of 5-10 $\mu \mathrm{m}$. 
Treatments 3 and 4 . The juice purification was performed using zeolite-clinoptilolite sorbent in the amount of $1.0 \%$ to the weight of the juice at a temperature of $40{ }^{\circ} \mathrm{C}$ for $8-10$ min, followed by mechanical filtration on a polypropylene cartridge filter Ecosoft $2.5 \times 10$ "with a filtration degree of 5-10 $\mu \mathrm{m}$, ultrafiltration using Aquafilter TLCHF-2T membrane with a filtration degree of $0.02-0.1 \mu \mathrm{m}$ at an operating pressure of $0.1-0.15 \mathrm{MPa}$ (treatment 3), and ion exchange sorption of sorghum juice using ion exchange regenerating resins of mixed action DOWEXM-50 in the cation exchange resin in $\mathrm{H}^{-}$form to anion exchange resin in $\mathrm{OH}^{-}$form ratio of 1.2:1.0 (treatment 4).

\section{Determining the main technological quality indicators of sugar sorghum juice and food syrup}

The research was conducted using conventional methods of control and analysisexisting in the sugar industries and accepted in international practice (Kupchyk M. et al., 2007).

The content of total sugars, reducing substances, and sucrose was determined by the iodometric method (Shtangeyeva N.I. et al., 2000), which is based on the reduction of alkaline copper solution with a solution of reducing substances and quantification of reduced copper oxide (I).

The purity index was calculated as the ratio of the total sugars content in the product to the dry matter content multiplied by $100 \%$ (Kupchyk M. et al., 2007).

The starch content was determined by the Morell Do Voil method (Panova T. et al., 2010), which is based on measuring the optical density of the solution, acidified with acetic acid and treated with potassium iodide, using SF-46 spectrophotometer at a wavelength of $570 \mathrm{~nm}$.

The starch concentration was determined according to the calibration curve constructed on standard solutions.

The content of the macromolecular substances (MMS) and colloids was determined by the method of Dumanskyy and Harin, modified by Korolkov and Silina, which is based on the properties of hydrophilic colloids to coagulate in solution after the addition of ethanol, followed by their quantitative determination by the weight method (Kupchyk M. et al., 2007).

The protein content was determined by the method of Reva and Simakhina (with biuret reagent) using spectrophotometer SF-46 at a wavelength of $600 \mathrm{~nm}$ (Kupchyk M. et al., 2007).

Dry matter content (DM, \% to the weight of the product) was determined without sample preparation, at a temperature of $20^{\circ} \mathrm{C}$ by the refractometric method (Kupchyk M. et al., 2007) using refractometer RPL-3.

The activity of $\mathbf{H}^{+}$ions was determined by the potentiometric method (Kupchyk M. et al., 2007) using universal ionometer EV-74.

The colour of the solutions was determined by photometric method, i.e. measuring the optical density of the solutions using photoelectrocolourimeter KFK-3, in a 10-mm cuvette, at a wavelength of $560 \mathrm{~nm}$ (Shtangeyeva N.I. et al., 2000).

\section{Order of research}

The application rate of zeolite for sorghum juice was $0-2.0 \%$ to the weight of juice. After stirring for 8-10 min, the precipitate was separated by filtration. Colour (Shtangeyeva N.I. et al., 2000) and MMS content (Kupchyk M. et al., 2007) were determined, and the 
efficiency of decolourisation (Herasymenko O.A et al., 1992) and MMS removal (Herasymenko O.A et al., 1992) was calculated.

At the next technological stage, for the most complete extraction of MMS and colour compounds from sorghum juice, after treatment with zeolite in the amount of $1.0 \%$ tothe weight of juice at a temperature of $40{ }^{\circ} \mathrm{C}$ for $8-10 \mathrm{~min}$, it was envisaged to carry out additional purification of the juice by membrane filtration methods, namely mechanical filtration (treatment 2), mechanical and ultrafiltration (treatment 3), with supplementing previous method by ion exchange purification (treatment 4). Juice purification using PHMGHC (treatment 1 ) was used as a control.

At the next stage of research, to obtain an organic syrup from sugar sorghum juice, which would have improved technological quality and functional health properties, there is a need to replace the technology of purification using synthetic flocculant PHMG HC with a natural absorbent. Therefore, treatments 3 and 4 involved the use of the natural mineral sorbent zeolite-clinoptilolite in sorghum juice purification.

\section{Statistical analysis}

Data were expressed as mean \pm standard deviation for three replications. Mathematical processing of the experimental data was performed using Mathcad Professional 2000 and Microsoft Excel 2007. The differences were considered significant at the LSD $\alpha=0.95$.

\section{Results and discussion}

\section{Study of methods of sugar sorghum juice purification and the quality of the obtained food syrups}

The adsorption properties of zeolite-clinoptilolite are determined by its structure, which consists of silicon tetrahedra and alumina octahedral (Taran N.G.,1983). The high ion exchange activity of clinoptilolite is associated with the content of $\mathrm{Al}^{3+}$ ions (Milovych $\mathrm{S}$. et al., 2010). In the case of natural sorbent, physicochemical processes of the interaction between anions of macromolecular and colouring compounds of sorghum with $\mathrm{Al}^{3+}$ cations of the sorbent occur due to specific adsorption forces because of their high polarization ability (Wanga Sh. et al., 2010).

In order to establish a rational application rate of zeolite-clinoptilolite and the duration of the process of sorghum juice purification, we carried out studies. Their results are given in Table 4.

The high efficiency of purification of sorghum juice is achieved by treating it with zeolite-clinoptilolite at an application rate from 0.3 to $1.5 \%$ to the weight of juice and the duration of 4-8 min. At such an application rate, a decrease in the content of the MMS was noted, which led to a decrease in the colour of sorghum juice. The optimal application rate can be considered $0.8-1.0 \%$ to the weight of juice, which ensures discolouration efficiency from 41 to $46 \%$, and the efficiency of MMS removal from 20 to $22 \%$. The obtained results are consistent with the conclusions of other studies (Husiatynska N. et al., 2018). 
Table 4

Technological characteristics of the purified sorghum juice as affected by the application rate of zeolite-clinoptilolite and the duration of the process

\begin{tabular}{|l|l|l|l|l|l|l|}
\hline \multirow{2}{*}{ Index } & \multicolumn{6}{|l|}{ Application rate of reagent, \% to juice weight } \\
\cline { 2 - 7 } & $\mathbf{0 . 1}$ & $\mathbf{0 . 3}$ & $\mathbf{0 . 5}$ & $\mathbf{1 . 0}$ & $\mathbf{1 . 5}$ & $\mathbf{2 . 0}$ \\
\hline Dry matter (DM), \% & 16.0 & 16.0 & 16.1 & 16.1 & 16.1 & 16.2 \\
\hline $\mathrm{H}^{+}$activity & 5.13 & 5.13 & 5.13 & 5.13 & 5.13 & 5.13 \\
\hline Colour, ICUMSA units & 905.6 & 736.6 & 697.8 & 507.3 & 508.2 & 516.7 \\
\hline Decolouration efficiency, \% & 3.68 & 21.65 & 25.78 & 46.04 & 45.95 & 45.04 \\
\hline MMS, \% to DM & 8.43 & 7.34 & 6.95 & 6.75 & 6.71 & 6.68 \\
\hline Efficiency of MMS removal, \% & 2.54 & 15.14 & 19.65 & 21.96 & 22.43 & 22.77 \\
\hline
\end{tabular}

The high efficiency of purification of sorghum juice is achieved by treating it with zeolite-clinoptilolite at an application rate from 0.3 to $1.5 \%$ to the weight of juice and the duration of 4-8 min. At such an application rate, a decrease in the content of the MMS was noted, which led to a decrease in the colour of sorghum juice. The optimal application rate can be considered $0.8-1.0 \%$ to the weight of juice, which ensures discolouration efficiency from 41 to $46 \%$, and the efficiency of MMS removal from 20 to $22 \%$. The obtained results are consistent with the conclusions of other studies (Husiatynska N. et al., 2018).

Study of the efficiency of purification of sugar sorghum juice using membrane technology

Technological characteristics of sorghum juice obtained in different treatments are presented in Table 5.

Table 5

Technological characteristics of purified sorghum juice

\begin{tabular}{|c|c|c|c|c|}
\hline Index & $\begin{array}{c}\text { Treatment } 1 \\
\text { (control) }\end{array}$ & $\begin{array}{c}\text { Treatment } \\
2 \\
\end{array}$ & $\begin{array}{c}\text { Treatment } \\
3 \\
\end{array}$ & $\begin{array}{c}\text { Treatment } \\
4\end{array}$ \\
\hline $\mathrm{H}^{+}$activity & 5.22 & 5.22 & 5.22 & 4.99 \\
\hline Dry matter (DM), \% & 17.2 & 16.8 & 16.6 & 16.5 \\
\hline $\begin{array}{l}\text { Macromolecular compounds } \\
\text { (MMS), \% DM }\end{array}$ & 5.60 & 6.40 & 3.32 & 1.18 \\
\hline Proteins, $\%$ & 0.30 & 0.37 & 0.12 & 0.01 \\
\hline Colour, ICUMSA units & 254.0 & 469.7 & 245.8 & 128.9 \\
\hline Total sugars, $\%$ & 15.62 & 14.70 & 15.06 & 15.12 \\
\hline $\begin{array}{l}\text { Reducing sugars: } \\
\text { \% to product weight } \\
\% \text { DM }\end{array}$ & $\frac{5.82}{33.84}$ & $\frac{5.35}{31.85}$ & $\frac{5.23}{31.50}$ & $\frac{5.09}{30.85}$ \\
\hline $\begin{array}{l}\text { Sucrose: } \\
\% \text { to product weight } \\
\% \mathrm{DM}\end{array}$ & $\frac{9.80}{56.97}$ & $\frac{9.35}{55.65}$ & $\frac{9.83}{59.22}$ & $\frac{10.03}{60.79}$ \\
\hline Purity, $\%$ & 90.81 & 87.50 & 90.72 & 91.64 \\
\hline
\end{tabular}


Analysis of technological characteristics of purified juice (Table 5) confirmed that the use of cationic flocculant PHMG HC, mechanical and ultrafiltration in treatment 1 (control) improves the quality of purified juice by precipitating MMS and colour compounds, which reduces the colour to 254.0 ICUMSA units and increase juice purity to $90.81 \%$. This is consistent with the findings of previous studies (Hryhorenko N. et al., 2020).

It should be noted that in today's conditions (Grygorenko, N. et al., 2019) when there is a trend of excessive consumption of simple carbohydrates and synthetic sweeteners by the population, the need for organic and environmentally friendly products is becoming increasingly important. Therefore, we came to a reasonable decision, that is to withdraw chemical reagent PHMG HC from the technological process of sorghum juice purification (Hrushetskyi R.I. et al., 2016).

However, treatment 2, that is the use of only membrane filtration methods after preand adsorption purification of the juice, did not ensure its proper purification from macromolecular and colour compounds. Thus, the MMS content in purified sorghum juice remained quite high $(6.40 \%)$, which significantly affected its colour, the value of which was quite high and amounted to 469.7 ICUMSA units. Accordingly, under such conditions, the purification of the juice did not significantly increase its purity $(87.50 \%)$.

\section{Efficiency sorghum sugar juice purification using zeolite}

Comparative data on the technological quality of purified juices in treatments 3 and 4 (Table 5) confirmed the correct choice of purification method, which provides the most complete removal of MMS and colour compounds and improves its quality, including purity.

Thus, under the conditions of using zeolite-clinoptilolite, mechanical filtration, and ultrafiltration, there is a significant improvement in the technological characteristics of sorghum juice (treatment3). Under such conditions, sorghum juice was obtained with a purity of $90.72 \%$ and a colour of 245.8 ICUMSA units, which indicates the high productivity of the ultrafiltration process in combination with absorption purification of the juice with zeolite to remove suspensions substances, MMS and colouring compounds.

It should be noted that in treatment3, supplemented with ion exchange purification, we obtained purified juice with the lowest indicators in terms of MMS content $(1.18 \%)$ and protein content $(0.01 \%)$. Thus, treatment 4 provided the highest efficiency in the extraction of MMS and colouring compounds. The colour of the juice decreased almost twice compared to treatment 3 and amounted to 128.9 ICUMSA units. The purity of the purified juice was also the highest (91.64\%) and comparable to all proposed methods of purification.

Confirmation of these research results is the efficiency of purification, MMS, and protein substances removal from sugar sorghum juice by the studied methods (Figure 1).

Thus, studies have shown that the best efficiency of sorghum juices purification was observed in treatments 3 and 4, specifically, absorption purification using zeoliteclinoptilolite, mechanical and ultrafiltration (treatment3), which ensured purification efficiency, removal of MMS and proteins of 46.1\%, $82.3 \%$, and $69.5 \%$, respectively. Under the conditions of absorption purification by zeolite-clinoptilolite, mechanical filtration, ultrafiltration, and ion exchange purification (treatment4), purification efficiency, removal of MMS and proteins amounted to $51.9 \%, 98.5 \%$, and $89.2 \%$, respectively. 


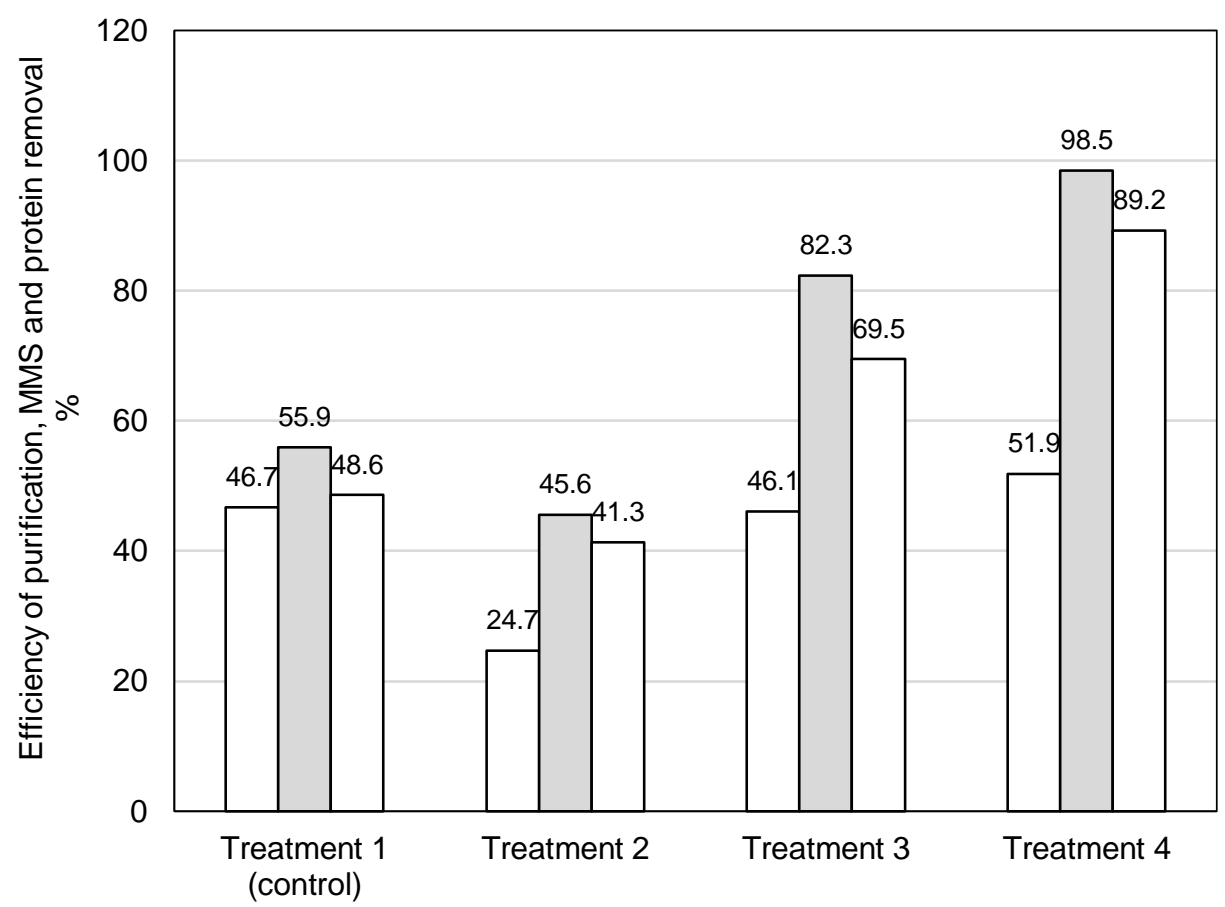
口Efficiency of purification, \%
口Efficiency of protein compounds removal, \%
口Efficiency of MMC removal, \%

Figure 1. Efficiency of purification, MMS and protein compounds removal from sugar sorghum juice by different purification methods

\section{Study of methods of purification of sugar sorghum juice on the quality of the obtained food syrups}

The results of the studies on sensory and physicochemical characteristics of syrups obtained in accordance with the proposed methods of juice purification are presented in Table 6.

Analysis of the experimental data (Table 6) shows that the purification methods 1 and 2 did not fully ensure the removal of MMS and colouring compounds. A high colour index of the product due to the high content of MMS, proteins and colouring compounds was observed in the juices obtained by the relevant purification treatments. In addition, in the process of juice concentration to syrup at high temperatures, sugars enter into complex reactions of dehydration, melanoid formation (Mayar reaction), etc. (Eggleston G. et al., 2000; Vercellotti J. et al., 2010), which leads to intensive formation of colouring substances that affect food characteristics of the syrup in terms of colour and taste. 
Table 6

Comparative sensory and physicochemical characteristics of the syrups obtained by different methods of sorghum juice purification

\begin{tabular}{|c|c|c|c|c|}
\hline \multirow[t]{3}{*}{ Characteristics } & \multicolumn{4}{|c|}{ Obtained sugar sorghum syrups } \\
\hline & $\begin{array}{c}\text { Treatment } 1 \\
\text { (control) }\end{array}$ & Treatment 2 & Treatment 3 & Treatment 4 \\
\hline & \multicolumn{4}{|c|}{ Sensory characteristics } \\
\hline Look & $\begin{array}{c}\text { Curdy } \\
\text { consistency, } \\
\text { transparent } \\
\text { liquid }\end{array}$ & $\begin{array}{c}\text { Curdy } \\
\text { consistency, } \\
\text { untransparent } \\
\text { liquid }\end{array}$ & $\begin{array}{c}\text { Curdy } \\
\text { consistency, } \\
\text { transparent } \\
\text { liquid }\end{array}$ & $\begin{array}{c}\text { Curdy } \\
\text { consistency, } \\
\text { transparent } \\
\text { liquid }\end{array}$ \\
\hline Colour & Light-brown & Dark-brown & Yellow & Light-yellow \\
\hline \multicolumn{5}{|c|}{ Physical and chemical characteristics } \\
\hline $\mathrm{H}^{+}$activity & 5.25 & 5.24 & 5.22 & 4.87 \\
\hline Dry matter (DM), \% & 74.5 & 73.5 & 73.4 & 74.2 \\
\hline Colour, ICUMSA units & 540.2 & 612.9 & 99.8 & 86.7 \\
\hline Total sugars, $\%$ & 67.52 & 64.20 & 66.48 & 68.05 \\
\hline $\begin{array}{l}\text { Reducing sugars: } \\
\% \text { to product weight } \\
\% \text { DM }\end{array}$ & $\frac{25.72}{34.52}$ & $\frac{24.72}{33.63}$ & $\frac{23.68}{32.26}$ & $\frac{23.20}{31.27}$ \\
\hline $\begin{array}{l}\text { Sucrose: } \\
\% \text { to product weight } \\
\% \text { DM }\end{array}$ & $\frac{41.80}{56.11}$ & $\frac{39.48}{53.72}$ & $\frac{42.80}{58.31}$ & $\frac{44.85}{60.44}$ \\
\hline Purity, \% & 90.63 & 87.35 & 9.57 & 91.71 \\
\hline
\end{tabular}

Confirmation of these assumptions is a more rapid increase in reducing sugars in the process of technological purification of juice and thickening to syrup in treatments 1 and 2 (Table 6), which led to a more intense increase in colour due to the interaction of monosaccharides with amino acids at a high temperature (Bugaenko I.F. et al., 2002).

At the same time, treatment 3 provided quite good results in terms of syrup quality $(99.8$ ICUMSA units) and purity $(90.57 \%)$. The best results of the quality of the syrup were obtained in treatment 4 , with a colour of 86.7 ICUMSA units and a purity of $91.71 \%$. Also, in these methods, there is no significant rearrangement in sugars, which indicates resourcesaving conditions of technological processes of juice purification and thickening to syrup. In addition, it should be noted that these methods of purification are better from a sanitary point of view (Glebov A.B. et al., 2013) because they do not involve soluble chemical reagents (Patent 147898 Ukraine). To sum up the experimental data, it can be stated that the methods of sorghum juice purification used in treatments 3 and 4 are efficient in removing MMS, proteins and colour compounds and ensure obtaining of transparent yellow and slightly amber syrup with a pleasant odour and balanced the optimal ratio of carbohydrates sucrose and glucose, fructose $(65: 35 \%$ mass). This fact makes it possible to recommend syrup for consumption as a natural sweetener. In addition, the developed technologies ensure the preservation of natural amino acids. We identified 19 amino acids in the products, of which seven are essential (threonine, valine, methionine, isoleucine, leucine, phenylalanine, and lysine). Of the minerals that are essential for human health, we found seven (iron, nickel, 


\section{Food Technology}

zinc, copper, cobalt, manganese, chromium) vital trace elements that are necessary for metabolic processes, as a part of the molecules, enzymes, hormones, and vitamins. The obtained products contain micronutrients in the amount of about $2 \%$ to DM. The presence of amino acids and minerals necessary for the human body indicates their significant nutritional and biological value.

Accordingly, the syrup obtained by purification methods used in treatments 3 and 4, namely adsorption purification, membrane filtration, and ion exchange purification, can be used in organic food production and also be a ready-to-use sugar-containing product.

\section{Conclusion}

1. In the conditions of deteriorating food security and food quality, due to the use of synthetic sugar substitutes in food products instead of crystal sugar, the production of organic sugar-containing products from alternative feedstock, in particular, sugar sorghum, have big prospects.

2. It was found that juice purification methods that use zeolite adsorbent, mechanical filtration in combination with ultrafiltration, and ion exchange purification ensure obtaining an organic sugar-containing product with a well-balanced natural carbohydrate composition which can be widely used in the food industry as a sugar component.

3. The study shows the effectiveness of the natural adsorbent zeolite in improving the quality of sorghum juice, reducing its colour, and removing MMS and protein substances. At an application rate of zeolite of $0.8-1.0 \%$ to the weight of juice, the efficiency of discolouration is $41-46 \%$, and the efficiency of MMS removal is $20-22 \%$.

4. It is experimentally determined that the use of zeolite for the purification of sorghum juice in combination with membrane filtration methods, such as mechanical filtration and ultrafiltration (treatment 3) provides the efficiency of purification, MMS and proteins removal and at the level of $46.1 \%, 82.3 \%$, and $69.5 \%$, respectively. Under the conditions of supplementing the above-mentioned treatment with ion exchange purification (treatment 4) we obtained an increase in the efficiency of purification, MMS and proteins amounted to $51.9 \%, 98.5 \%$, and $89.2 \%$, respectively.

\section{References}

Costa G. H. G., De Freita C. M., De Freita L. A. \& Mutton M. J. R. (2015), Effects of Different Coagulants on Sweet Sorghum Juice Clarification, Sugar Tech, 17, pp. 210-213, DOI: $10.1007 / \mathrm{s} 12355-014-0332-3$

Csefalvay E. \& Bakacsi Z. (2019), Chemical-free Processing of Sweet Sorghum Juice of Cultivar Sucro sorgho 506, Periodica Polytechnica Chemical Engineering, 63(1), pp. 3650, DOI: 10.3311/PPch.12056.

Dow Chemical. Dowexmb-50, Available at: https://filtryvoda.org.ua/files/dowex_mb50.pdf

Eggleston G. \& Vercellotti J. R. (2000), Degradation of Sucrose, Glucose and Fructose in Concentrated Aqueous Solutions Under Constant pH Conditions at Elevated Temperature, Journal of Carbohydrate Chemistry, 19, pp. 1305-1318, DOI: 10.1080/07328300008544153

Eggleston G., Heckemeyer M., Cyr E.S. \& Wartelle L. (2016), Case Study: Commercialization of Sweet Sorghum Juice Clarification for Large-Scale Syrup Manufacture, Sugar Tech, 18, pp. 249-257, DOI: 10.1007/s12355-015-0387-9 
Eggleston G., Marsha C. \& Andrzejewski B. (2013), New Commercially Viable Processing Technologies for the Production of Sugar Feed stocks from Sweet Sorghum (Sorghum bicolor L. Moench) for Manufacture of Biofuels and Bioproducts, Sugar Tech, 15(3), pp. 232-249, DOI: 10.1007/s12355-013-0229-6

Gembickij P.A., Voinceva I.I. (1998), Polimernyj biocidnyj preparat poligeksametilenguanidin, Poligraf, Zaporizhzhia.

Glebov A.B., Ignatov I.V., Mironova G.S. (2013), Analiz sveklosemyan, syrya, gotovoj $i$ pobochnoj produkcii saharnogo proizvodstva po pokazatelyam bezopasnosti, GP «Ukrmetrteststandart», Kyiv.

Grigorenko N., Shtangeev V., Khomichak L. \& Grinenko I. (2016), Ways to find an expansion of the range of products of the sugar industry of Ukraine, Sugar of Ukraine, 67(126-127), pp. 41-44.

Grigorenko N.O., Shtangeyeva N.I. (2017), Udoskonalennya sposobu viluchennya cukriv iz stebel sorgo, Prodovolchi resursi: zbirnik naukovih prac. IPR NAAN Ukraine, 9, pp. $150-153$

Grygorenko N., Cherednychok O., Babiazh A., Grygorenko A. (2019), Innovative technology for the production of organic sugar syrup obtained from sweet sorghum and its use for the production of healthy foods, $4^{\text {th }}$ International Scientific Conference. Agrobiodiversity for Improve the Nutrition, Health and Quality of Human and Bees Life, Nitra, p. 87.

Herasymenko O.A, Khvalkovskyi T.P. (1992), Metody analizu i kontroliu $u$ vyrobnytstvi tsukru, Vyshcha shkola, Kyiv, pp. 388.

Hrushetskyi R.I., Hrinenko I.H., Khomichak L.M. (2016), Pryrodni dzherela zdorovia, Ahrarna nauka, Kyiv.

Hryhorenko N., Husiatynska N., Vakuliuk P. \& Chibrikov V. (2020), Improvement of technology for obtaining sugar-containing sorghum syrup with the use of membrane methods, Scientific Works of National University of Food Technologies, 26(1), pp. 142-152.

Hryhorenko N.O., Bilostotskyi L.H., Shtanheieva N.I., Kutsekon I.P. (2007), Hidroliz krokhmaliu v soku tsukrovoho sorho, Kharchova i pererobna promyslovist, 5, pp. 29-30.

Husiatynska N., Nechypor T., Husiatynskyi M. \& Shulga S. (2018), Research into application of zeolite for purification of diffusion juice in sugar production, EasternEuropean Journal of Enterprise Technologies, 5/11(95), pp. 6-13.

Karputina M., Pribylsky V., Grigorenko N. \& Melnyk, I. (2014). New in the technology of soft drink obtained using the culture of Medusomycesgisevii, Scientific works Odesa National Academy of Food technologies, 46(2), pp. 86-91,

Kovtunova N.A., Kovtunov V.V. (2019). Ispolzovanie sorgo saharnogo v kachestve istochnika pitatelnyh veshestv dlya cheloveka (obzor literatury), Zernovoe hozyajstvo Rossii, 3(63), pp. 3-9. DOI: 10.31367/2079-8725-2019-63-3-3-9

Kupchyk M., Reva L., Shtanheieva N., Cherniavska L., Lipiets A., Khomichak L., Herasymenko O., Khvalkovskyi T., Klymenko L., Skoryk K., Lohvin V., Olianska S., Petrychenko I., Vyhovskyi V., Lahoda V., Husiatynska N., Miroshnyk V. \& Nychyk O. (2007), Sugar technology, pp. 393.

Mengoni O. (1976), Sorghum Sugar and Its Syrups, the Italian sugar industry Italy, 69(1) pp. 5-10.

Milovych S., Homonai V. \& Dzoba O. (2010), Research of properties of natural and modified clinoptilolite, Science, Bulletin of Uzhhorod University, Chemistry Series, 23, pp. 69-72. 


\section{— Food Technology —}

Nimbkar N., Kolekar N.M., Akade, J.H. \& Rajvanshi, A.K. (2006), Syrup production from Sweet Sorgum, National Agricultural Research Institute, Phaltan, India, pp.10, http://www.nariphaltan.org/syrup.pdf.

Ospankulova G., Kamanova S., Yunusov T., Beckuzhina S. \& Bulashev B. (2020), Method choice for processing sugar sorghum juice to prevent the formation of 5hydroxymethylfurfural in the syrup during storage, Eur Asian Journal of Bio Sciences, 14, pp. 1273-1280.

Panova T. \& Shcheholeva A. (2010), Technology and equipment for processing vegetable raw materials, Ekaterinburg.

Shtangeyeva N.I., Chernyavska L.I., Reva L.P. \& ed. (2000), Metodi kontrolyu harchovih virobnictv, Kyiv.

Taran N.G. (1983), Adsorbenti i ionity v pishevoj promyshlennosti, Moscow.

Umakanth A.V., Ashok Kumar A., Vermerris, W. \& Tonapi V.A. (2019), Breeding Sorghum for Diverse End Uses, Wood head Publishing Series in Food Series in Food Science, Technology and Nutrition, Chapter 16 - Sweet Sorghum for Biofuel Industry, pp. 255-270, DOI: 10.1016/B978-0-08-101879-8.00016-4

Vercellotti J., Vercellotti S., Kahn G. \& Eggleston G. (2010), Approaches to Raw Sugar Quality Improvement as a Route to Sustaining a Reliable Supply of Purified Industrial Sugar Feedstocks, American Chemical Society, 12, pp. 191-206,

Vukov K., Magar-Pichler E., Toth M. \& Barta J. (1987), Zucker hir sesirupe in Produkt für dietätische Lebensmittel «Zeitsehriftfurdie Zuckerindustrie», 112(8), pp. 709-712.

Wanga Sh., Peng Yu. (2010), Natural zeolites as effective adsorbents in water and wastewater treatment, Chemical Engineering Journal, 156, pp.11-24.

Willis O.O., Mouti M.E., Sila D.N. Mwasaru M., Thiongo G., Murage H. \& Ojijo N.O. (2013), Physico-Chemical Properties and Antioxidant Potential of Syrup Prepared from 'Madhura' Sweet Sorghum (Sorghum bicolor L. Moench) Cultivar Grown at Different Locations in Kenya, Sugar Tech, 15, pp. 263-270, DOI: 10.1007/s12355-013-0222-0

ZAO NTC Vladipor (2005), Membrany. Filtruyushie elementy. Membrannye tehnologii, Vladimir.

Zhetkizgenkyzy G., Baygaziyeva G.I. \& Askarbekov E.B. (2016), Research of sugar sorghum syrup for soft drinks productionresearch of sugar sorghum syrup for soft drinks production, The journal of Almaty technological university, Issue 1(110), pp. 32-36. 